\title{
Preservice Chemistry Teacher Perception toward Contextual Learning Implementation of OLEDs in Organic Chemistry Learning
}

\author{
Septian Jauhariansyah ${ }^{1}$, Oczhinvia Dwitasari ${ }^{2}$, Ahmad Mudzakir ${ }^{3}$, Tuszie Widhiyanti ${ }^{4}$ \\ 1,2 Universitas Dehasen Bengkulu, Indonesia \\ ${ }^{3,4}$ Universitas Pendidikan Indonesia \\ septian.j@gmail.com,oczhinvia@gmail.com
}

\begin{abstract}
This study aimed to explore chemistry pre-service teacher view toward implementation of contextual learning in Organic Chemistry. The context that was investigated about is Organic Light Emitting Diodes (OLEDs), which was a novel display technology that is being used for smartphone display. Seventeen pre-service chemistry teachers were interviewed about their knowledge about organic chemistry, conjugated double bond, OLEDs and their view about implementing OLEDs context in organic chemistry learning. Three groups of questions were asked to the pre-service chemistry teacher, most of them indicating lack knowledge about detail information of OLEDs even though they really appreciate if OLEDs was introduced in Organic Chemistry learning especially in conjugated double bond and nature-generated organic compound topics.
\end{abstract}

Keywords

Contextual leaming, organic chemistry, $\mathrm{OAD}$ s, preservice chemistry teacher

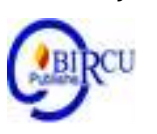

\section{Introduction}

Rapid changes of technology and information has brought new demands about competences that should be mastered by human through education. To fulfil those demands Indonesian Government has made some adjustment in Indonesian national curriculum and education system. This was done as a respond to prepare the younger generation for future condition. The Graduation Competences Standard (SKL) in 2013 Curriculum - revised stated that high school graduate should at least mastered four dimensions of knowledge and has ability to implement it in many contexts (Kemdikbud, 2016). These demands in school competences standard would cause some adjustment in teacher instruction in class.

Conceptual understanding and implementation in some contexts were related to the scientific literacy. Program of Internationals Students Assessment (PISA) 2015 stated that, scientific literacy has four main components which are knowledge; competences; attitude and context (OECD, 2016). The autonomy of the education sector seeks to condition schools so that principals, teachers have a great responsibility in improving the quality of the learning processto improve the quality of learning outcomes (Prasetyo et al, 2019).

Indonesia has participated in PISA several times, though the result still unsatisfied for our education. Almost $60 \%$ of the students sampled for PISA 2015 only reached level 1a to level 2, and there were no Indonesian students who reached level 5 or even level 6 (OECD, 2016). According to PISA 2015 assessment description, Indonesian students did not have ability to implement scientific concepts that have been mastered by them in real context. Even though the sampling technique that used in PISA still uncleared, the result described how the students struggle to implement their understanding in real context. This 
is the reason why the contextual learning is so important for our students (Bybee and Fuchs, 2006).

Tala (2013) stated that to be able to master and implement scientific concept in a certain context, scientific learning in school should be integrated with the context. One of the contexts that was close to the students today is technology. Gardner (1994) stated that science and technology could not be separated, because they have two ways relationship.

According to the Indonesian Dictionary, development is a process / way, the act of developing. In term of development, it shows that an activity produces a new tool or method, during which the activity will continue to be evaluated and improved to improve quality. So that development can be defined as a plan to develop something that already exists in order to improve the quality of more advanced (Ediyani et al, 2020). The development of technology, communication and information, especially the internet has become a demand for teachers in Indonesia to be able to use it as a source of positive learning media in supporting teaching and learning processes (Prasasti, 2019).

The idea of integrating technology to science learning at school was started in the late of 1980's in form of Science - Technology - Society (STS) approach (Bybee, 1987). The STS approach was actually a learning that provide students with problems or issues that related to technology and science in society. The students were asked to be able to solve the problems in scientific manner (Poedjiati, 2005).

The importance of integrative science and technology learning need teacher that has ability to deliver science and technology in form of contextual learning. Tala (2009) stated that to present an accurate scientific concept in form of contextual learning, the teacher should be trained to connect scientific concept with the technological context. For that reason, preparing a science teacher for mastering ability to integrate scientific concept in technological context was very important. This study was a part of bigger study that constructing contextual learning for preservice science teacher.

Implementing novel technology in science learning became a major point for constructing a contextual learning in science. One of a novel technology that close to human daily life today was the display technology. Organic Light-emitting Diodes (OLEDs) display has been rapidly growth in the decades. Tsujimura (2012) stated that OLEDs was a light emission technology which could be fabricated in flexible way in a thin layer because the components used in it was quite simple compared to Liquid Crystal Display (LCD).

Itoh (2009) introduced a form of OLEDs that was very simple called Electro Chemicoluminescence (ECL) cell. The fabrication of ECL was using an organic semiconductor and solvent. Adijaya (2011) successfully fabricated an ECL cell which utilized compounds that was extracted from daily organic material. This showed that implementing OLEDs context in science learning is possible.

Construction of learning environment require several steps. One of construction framework was called Model of Educational Reconstruction (MER) (Neibert and Gropsengiesser, 2013). MER consisted of three main steps which are (i) Concept classification; (ii) Inverstigation of learning result and process; and (iii) Construction of learning program (Duit et al., 2012). This article will describe what we do in the second step of MER which aimed planning a construction of integrative learning which utilize OLEDs context in organic chemistry course. 


\section{Research Methods}

The second step of MER was an investigation toward learning process and result that had been done before. The aim was to get insight of preservice teacher knowledge before introducing to the context (Duit et al., 2012). A structured interview was administered to several preservice teachers that had finished their course in organic chemistry in last semester. 17 preservice teachers participated in this interview will be called respondent. There were 20 questions which grouped in 3 sections.

Every interview section was recorded using an android smartphone with an Operating System Android 9.0 and Parrot recorder application. The interview then transcript and then analysed to get the core of their responds.

\section{Results and Discussion}

\subsection{Result}

The interview result was presented in Table 1:

Table 1. Analysed Interview Respond

\begin{tabular}{|c|c|c|c|}
\hline $\mathbf{N r}$ & Questions & Respond & Total Respond \\
\hline \multicolumn{4}{|c|}{ Organic Compound Knowledge } \\
\hline 1 & $\begin{array}{l}\text { Example or organic } \\
\text { compound }\end{array}$ & $\begin{array}{l}\text { Could state several examples of } \\
\text { organic compound }\end{array}$ & 17 \\
\hline \multirow[t]{4}{*}{2} & $\begin{array}{l}\text { Defining organic } \\
\text { compound }\end{array}$ & $\begin{array}{l}\text { Organic compound was a compound } \\
\text { that has bond between } \mathrm{C} \text { atom and } \\
\text { non-C atom such as } \mathrm{H}, \mathrm{O}, \mathrm{P}, \mathrm{N} \text {, and } \\
\mathrm{S} \text {. }\end{array}$ & 11 \\
\hline & & $\begin{array}{l}\text { Organic compound was a compound } \\
\text { collected from nature }\end{array}$ & 2 \\
\hline & & $\begin{array}{l}\text { Organic compound was a compound } \\
\text { which has group of } \mathrm{C} \text { and } \mathrm{H} \text {. }\end{array}$ & 2 \\
\hline & & $\begin{array}{l}\text { Organic compound is carbon } \\
\text { compound }\end{array}$ & 2 \\
\hline 3 & $\begin{array}{l}\text { Property and structure } \\
\text { relationship }\end{array}$ & $\begin{array}{l}\text { Realizing there is relationship } \\
\text { between property and structure and } \\
\text { explaining the example }\end{array}$ & 17 \\
\hline \multirow[t]{2}{*}{4} & $\begin{array}{l}\text { Explaining organic dye } \\
\text { based on the structure }\end{array}$ & $\begin{array}{l}\text { Explaining conjugated double bond } \\
\text { in organic dye }\end{array}$ & 4 \\
\hline & & Could not give any explanation & 13 \\
\hline & & LEDs technology knowledge & \\
\hline \multirow[t]{2}{*}{5} & $\begin{array}{l}\text { OLEDs as a light } \\
\text { emission technology }\end{array}$ & $\begin{array}{l}\text { Has knowledge about } \\
\text { technology }\end{array}$ & 4 \\
\hline & & $\begin{array}{l}\text { Has no any knowledge about OLEDs } \\
\text { technology }\end{array}$ & 13 \\
\hline \multirow[t]{2}{*}{6} & $\begin{array}{l}\text { Differentiate } \\
\text { conventional LED and }\end{array}$ & $\begin{array}{l}\text { Could differentiate it based on the } \\
\text { material that being used }\end{array}$ & 15 \\
\hline & OLEDs & Could not give any conclusion & 2 \\
\hline \multicolumn{4}{|c|}{ Connecting the chemistry concept with the OLEDs technology } \\
\hline 7 & $\begin{array}{l}\text { Identified double bond } \\
\text { in organic materials } \\
\text { used in OLEDs }\end{array}$ & $\begin{array}{l}\text { Could identify the conjugated double } \\
\text { bond }\end{array}$ & 17 \\
\hline
\end{tabular}


8 Stating organic material Conclude that the conjugated double

for light emission in bond was a crucial point for light

OLEDs

emission in OLEDs

Could not give any explanation 2

9 The role of organic The natural organic compound did

electrolyte in OLEDs not need the electrolyte

structure

The natural organic compound does

need the electrolyte

Other irrelevant answer regarding

electrolyte role

\subsection{Discussion}

\section{a. Basic Organic Compound Knowledge}

The first part or interview was designed to discover how deep preservice chemistry teacher knowledge in organic chemistry concepts. Based on the interview, it was discovered that the respondents have enough knowledge in organic chemistry concepts. Even though, the respondents could not give a clear explanation when several concepts were asked in a contextual way. The concept regarding organic dye that need explanation about Highest Occupied Molecular Orbital (HOMO); Lowest Unoccupied Molecular Orbital (LUMO); and conjugated double bond concepts. It was discovered that most of the respondents had difficulty to give the explanations.

The inability of the respondents to give clear explanations in simple context of organic dye was quite interesting, because the respondents could give clear and deep explanations regarding the concept, but they could explain the same way in the context related to the concept. This was indicating that most of the respondents was lacking experience to explain daily phenomenon using their knowledge in science. Kanfer and Ackerman (1989) proposed an idea to solve this condition by repeating and habituating preservice teacher to use their knowledge about science concept to give explanation on a certain phenomenon.

\section{b. OLEDs Technology Knowledge}

The Table 1 showed that most of the respondents was lacking the knowledge in OLEDs technology. Through the interview, it was known that most of the respondent was familiar with the term LCD or LED, but the term OLEDs was relatively new to them. This indicating that most of the respondents were not exposed to the current display technology such as OLEDs. This also could be the reason why, teacher in school still used outdated context in their teaching.

As the result showed that most of preservice teacher has lack information about OLEDs so basic text about OLEDs was administered to introduce OLEDs technology to them. Then the interview was continued to investigate their ability to identify organic compounds structure that used as emitting agent in OLEDs. The result show that most of the respondents could identify the structure easily since they had enough knowledge in organic chemistry. 


\section{c. Implementing Organic Chemistry Concepts in Light Emission in OLEDs}

The last section of the interview was to investigate if the respondents could conclude that natural organic compounds was a potential emitting agent for OLEDs. The result showed that there still were several respondents who could not conclude, they give irrelevant answers even though most of them state clearly that the emitting agent has conjugated double bonds, the organic dye also has conjugated double bond, they still did not have any clue that a natural compound such as anthocyanin which have double bond and could be used as organic dye have potential an emitting agent in OLEDs.

Most of the respondents also could not give clear explanations regarding the light emission in OLED even though they could explain abstract concept such as HOMO and LUMO clearly. It was quite understandable since in course most of the time explanation about light emission usually discussed in inorganic chemistry course.

The lack of preservice chemistry teacher ability to explain and relating science concept to a novel context generally caused by their lack of experience in integrating context to explain science concept. This was agreed by the respondents that stated most of their course in chemistry was actually just focused on subject matter without integrating context in it. They really appreciated the idea to implementing a contextual learning using OLEDs in their course in organic chemistry, since they will be the future teacher, so they need to understand novel technology related to science concept started with OLEDs.

\section{Conclusion}

The result showed that even though the preservice teacher has enough knowledge in science concept - in this case organic chemistry, most of them was lacking the ability to explain technology context related to the concept that they understand. This was caused by their lack in experience to integrate context especially novel technology context to delivering the subject. A learning design that could provide the experience for preservice teacher to integrate science and novel technology was really important to be constructed.

\section{References}

Adijaya, A. (2011). Fabrikasi dan Karakterisasi Material Gel Pemancar Cahaya Menggunakan Elektrolit Kristal Cair Ionik cis-Oleil-Imidazolinium Iodida dan Emitter Ekstrak Tumbuhan. (Skripsi). Universitas Pendidikan Indonesia.

Bybee, R. (1987). Science education and the science-technology-society (S-T-S) theme. Science Education, 71(5), hlm. 667-683.

Bybee, R. W., \& Fuchs, B. (2006). Preparing 21st century wokforce: A new reform in science and technology education. Journal of Research in Science Teaching, 43(4), hlm. 349-352.

Duit, R., Gropengießer, H., Kattmann, U., Komorek, M., \& Parchmann, I. (2012). The model of educational reconstruction - A framework for improving teaching and learning science. Dalam D. Jorde \& J. Dillon (Penyunting), Science Education Research and Practice in Europe: Retrospective and Prospective (hlm. 13-37). Rotterdam: Sense Publisher.

Ediyani, et al. (2020). Study on Development of Learning Media. Budapest International Research and Critics Institute-Journal (BIRCI-Journal). P. 1336-1342.

Gardner, P. L. (1994). The relationship between technology and science: Some historical and philosophical reflections. Part I. International Journal of Technology and Design Education, 4(2), hlm. 123-153. 
Itoh, N. (2009). Electrochemical light-emitting gel made by using an ionic liquid as the electrolyte. Journal of The Electrochemical Society, 156(2), hlm. J37-J40.

Kanfer, R., \& Ackerman, P. L. (1989). Motivation and cognitive abilities: An integrative/aptitude-treatment interaction approach to skill acquisition. Journal of Applied Psychology, 74(4), hlm. 657-690.

Kemendikbud. (2016). Permendikbud Nomor 20 Tahun 2016 tentang SKL Pendidikan Dasar dan Menengah. Jakarta: Kemendikbud.

Niebert, K., \& Gropengießer, H. (2013). The model of educational reconstruction: a framework for the design of theory-based content specific interventions. the example of climate change. Dalam N. Nieveen \& T. Plomp (Penyunting), Educational Design Research - Part B: Illustrative Cases (hlm. 511-532). Enschede: SLO.

OECD. (2016). PISA 2015 Results in Focus.

Poedjiadi, A. (2005). Sains Teknologi Masyarakat Model Pembelajaran Kontekstual Bermuatan Nilai. Bandung: Remaja Rosdakarya.

Prasasti, T.I., et al. (2019). The Effectiveness of Learning Media Folklore Text of North Sumatera Based on Blended Learning by 10th Grade Students of Vocational High School Harapan Mekar-1 Medan. 480-490

Prasetyo, G., et al. (2019). Modern Paradigm: Democratic Skills in a Higher Order Thinking Skills Frame. Budapest International Research and Critics Institute-Journal (BIRCI-Journal). P. 150-159.

Tala, S. (2009). Unified view of science and technology for education: technoscience and technoscience education. Science and Education, 18(3-4), hlm. 275-298.

Tala, S. (2013). The nature of technoscience (NOTS). Dalam M. P. Clough, J. K. Olson, \& D. S. Niedeshauser. (Penyunting), The Nature of Technology - Implication for Learning and Teaching (hlm. 51-84). Rotterdam: Sense Publisher.

Tsujimura, T. (2012). OLED Display Fundamental and Applications. New Jersey: John Wiley \& Sons. 